\title{
Communication Strategy In The Digital-Age for Delivering Knowledge at Islamic Boarding Schools Through E-Learning
}

\author{
Rila Setyaningsih ${ }^{1}$, Abdullah $^{2}$, Edy Prihantoro $^{3}$, Hustinawaty $^{4}$ \\ \{rilasetya@unida.gontor.ac.id ${ }^{1}$, abdullah@unidagontor.ac.id ${ }^{2}$, edipri@staff.gunadarma.ac.id ${ }^{3}$, hustina@ staff.gunadarma.acid ${ }^{4}$ \}
}

University of Darussalam Gontor ${ }^{1,2}$, University of Gunadarma ${ }^{3,4}$

\begin{abstract}
The purpose of this research is to analyze the communication strategy in the digital-age for delivering knowledge at an Islamic boarding school. The method used in this research is qualitative. Data collection was done through observation and interviews with lecturers of five basic subjects in the Communication Studies Program at the University of Darussalam Gontor as the Islamic boarding school university. The result of this research is a communication strategy in the digital-age for delivering knowledge at Islamic boarding schools is conducted with a selection of learning media in the form of an e-learning portal. The criteria for selecting and determining learning media are conducted by considering ACTIONS (Access, Cost, Teaching and Learning, Interactivity, Organizational Issues, Novelty, and Speed) factors. The contribution of this research is a communication strategy in the digital-age for delivering knowledge at Islamic boarding schools conducted through e-learning.
\end{abstract}

Keywords: Communication Strategy, Digital Age, Islamic boarding school, Learning Media, E-Learning.

\section{Introduction}

The emergence of the digital era has resulted in a transformation process that has an impact on the changes in the world of education as well as in Islamic boarding schools. Islamic boarding schools institutions that have long applied the textual education model by studying the books, now face new challenges with the emergence of the digital era. It is necessary and important to shift learning models in some Islamic boarding schools institutions, especially modern Islamic boarding schools. Learning models that were limited to the use of textual books and sorogan models need to be adapted to the contextual learning model through the use of digital media in the learning process, especially in modern Islamic boarding schools.

Based on the results of preliminary observations, it is known that the learning model at Darussalam Gontor University as a university based on modern Islamic boarding school still uses the lecture model and is dominated by the use of textbooks as references, the use of digital media is still very limited. On the other hand, innovation to update learning models especially in the introduction of ICT (Information and Communication Technology) is a demand for education in modern Islamic boarding schools.

Modern Islamic boarding schools institutions have made a more fundamental reform because there have been several weaknesses in traditional Islamic boarding schools, namely in the field of curriculum that only teaches religious knowledge so that graduates cannot enter employment which requires general knowledge, mastery of technology and skills[1]. The introduction of technology to students can be done by utilizing digital media in the learning process.

Communication strategies to provide knowledge to students and the selection of appropriate learning media are important in facing the challenges and opportunities of Islamic boarding schools in the digital era. With the mastery of technology, Islamic boarding schools will have competitiveness with other general education institutions. The advantage is that when the public is concerned about moral decline due to the negative impact of technology, Islamic boarding schools are able to be a solution in preparing generations with noble character and able to utilize technology for positive activities.

The advantage of the Islamic boarding schools system compared to ordinary schools without a dormitory is that students are in an educational environment for 24 hours, and educators or caregivers can supervise, guide, and set an example for them. "Najamuddin stated that this would facilitate efforts to achieve educational goals so that the results could double from the results of ordinary school education. Students in Islamic boarding schools institutions are directed to get used to practicing the teachings of Islam "[2].

Communication strategies in learning at Islamic boarding schools are determinants of the success or failure of activities to provide knowledge to students effectively. A communication expert defines a communication strategy as the best combination of all communication elements ranging from communicators, messages, channels (media), recipients, and influences (effects) designed to achieve a goal[3]. According to Cangara, the strategies implemented in communication planning must be preceded by several steps, namely: selecting and assigning communicators, setting targets, techniques for composing messages, and choosing media or communication channels[4]. The discussion in this article focuses on Islamic boarding schools' communication strategy in providing knowledge in the digital era by selecting and determining learning media based on "ACTIONS" (Access, Cost, Teaching and Learning, Interactivity, Organizational Issues, Novelty, and Speed) factors.

The strategy of choosing the right learning media is the determinant of the success of the learning process. An article written by Mahnun in 2012 concluded that to choose the media in the learning process, what is needed is the ability of the teacher to understand the appropriate media selection steps and implementation in learning[5]. In 2016, Prastya conducted research which showed that teachers who could choose learning media correctly, ICEMSS 2018, December 7-8, Banyuwangi, Indonesia Copyright (C) 2019 
learning became effective so that learning objectives could be achieved optimally. This is shown through the achievement of satisfying student learning outcomes.

With the selection and use of appropriate learning media it is believed that students easily and quickly understand the material presented by the teacher[6]. Together with these two studies, this research seeks to explore further about the communication strategy in providing knowledge at Darussalam Gontor University. Selection of the right learning media can be a strategy to improve the quality of learning. The selection of Bates model learning media (1995) can be done by considering ACTIONS (Access, Cost, Teaching and Learning, Interactivity, Organizational Issues, Novelty, and Speed) factors[7].

This research is important to analyze communication strategies in conveying knowledge in Islamic boarding schools. This study supports the policy of the Ministry of Research, Technology and Higher Education of the Republic of Indonesia presented in Press Release No. 23/SP/HM/BKKP/III/2018 March 6, 2018, concerning Higher Education Policy Must Be Relevant to the Industrial Revolution 4.0[8]. In order to support government policy, this study aims to analyze communication strategies in the digital era in conveying knowledge at Darussalam Gontor University.

\section{Research Methods}

This study uses a qualitative descriptive method to analyze communication strategies in the digital era in conveying knowledge at Darussalam Gontor University. The data in this study was obtained through direct observation and in-depth interviews. Observations are carried out by directly observing the activities of the lecturers of basic courses in learning activities. Interviews were conducted with policymakers and lecturers at the UNIDA Gontor Communication Studies Study Program consisting of five basic subjects (Introduction to Communication Science, Communication Theory, Communication Psychology, Contextual Communication, and Mass Communication). The interviews were carried out regarding the selection and use of instructional media for basic courses. The interview focused on seven factors for selecting learning media, namely "ACTIONS" (Access, Cost, Teaching and Learning, Interactivity, Organizational Issues, Novelty, and Speed).

After conducting observations and in-depth interviews, researchers constructed messages obtained from informants and mapped out communication strategies conducted by lecturers in providing knowledge using new media in the form of e-learning. Data analysis techniques were carried out based on Miles and Huberman's theory, namely data reduction, data presentation, and conclusion drawing or data verification[9]. The reduction is made by summarizing, choosing the main things, and focusing on the important things.

Presentation of data in the form of brief descriptions, charts, relationships between categories, flowcharts and the like. Conclusion / verification withdrawal is the third line in data analysis techniques after data reduction and presentation. The validity of the research data is done by triangulation. According to Sugiono triangulation is a data collection technique that combines the various techniques and data sources available[10]. Triangulation of the data in this study using a triangulation method which is done by combining observation and interview techniques, and combining data sources from several research subjects.

\section{Results and Discussion}

This study found communication strategies in the digital era in providing knowledge at Darussalam Gontor University through e-learning. The choice of e-learning as a learning medium is determined based on ACTIONS (Access, Cost, Teaching and Learning, Interactivity, Organizational Issues, Novelty, and Speed) factors. The policymakers and lecturers of the basic courses at the Communication Science Study Program of Darussalam Gontor University have chosen e-learning as a medium that is considered capable of improving the quality of learning. Based on the results of observations it is known that the internet-based learning system or e-learning developed at Darussalam Gontor University aims to facilitate the learning process on campus both for lecturers as instructors and for students who are taught.

This learning model is very much needed with different campus location conditions. Through e-learning, students not only get the textual material but visual material such as image, video, and animation that can clarify understanding of the material. The success of this learning program can be seen from the increase in students' understanding of the courses in e-learning.

In choosing learning media to support the policy of the Ministry of Research, Technology and Higher Education of the Republic of Indonesia concerning Higher Education Policy Must Be Relevant With 4.0 Industrial Revolution, Communication Studies Program of Darussalam Gontor University chooses and develops learning media based on ACTIONS factors. The first factor is access, meaning that the learning media that will be used can be available, easy, and can be utilized. In 2018 Communication Science Study Program at Darussalam Gontor University developed e-learning.

Based on interviews with policymakers it is known that the development of e-learning aims to provide learning media that are relevant to the development of information and communication technology, facilitate the 
learning process, and facilitate lecturers in improving the quality of learning through the use of e-learning media developed. This corresponds with Purnomo's statement that various studies both at domestic and abroad indicate that the use of teaching materials packaged in ICT-based media can improve the quality of education[11].

The second factor in the selection of media is cost, which means that the media used is affordable. Based on the results of the interviews it is known that financing for e-learning can be reached so that it is not an obstacle. The next factor is in the form of teaching and learning, this relates to the ability of a learning media to become a bridge / intermediary of the message to be conveyed. E-learning developed at UNIDA Gontor further facilitates the learning process for lecturers and students.

This finding corresponds with Agustina's research which states that teachers or lecturers should no longer position themselves as knowledge authority holders but rather as mediators whose role is to facilitate a more participatory learning process. Consequently, the paradigm developed is no longer emphasizing teaching but more of aspects learning[12]. With the existence of e-learning, lecturer learning materials can also be better documented.

The fourth factor is interactivity, related to the level of ease of use of a media by lecturers and students. The learning media used can lead to two-way communication or interactivity, so that students will be involved / active both physically intellectually and mentally. E-learning makes the learning process easier because lectures do not have to be done face-to-face, but can be through virtual classes and able to increase student activity and creativity. This is in line with Darmayanti's research which states that the digital era raises a new paradigm about the learning process which no longer describes face-to-face meetings in the classroom, even though the concept of social interaction in it is maintaine[13].

The next factor is organizational issues. This factor is closely related to the impact caused by using a learning media on the organization of an educational institution. In other words, in choosing learning media organizationally get the support from the leader of the education institute (there are units who manage). The results of observations and interviews revealed that the choice of e-learning developed at Darussalam Gontor University received full support from the leader of the University, and the management was handled by PPTIK (Center for Information and Communication Technology Management) UNIDA Gontor.

The sixth factor is novelty, which means that the chosen learning media has novelty so that it has an attraction for college participants to study harder. E-learning developed is a new media in the implementation of learning in the Communication Science Study Program at Darussalam Gontor University which was developed with the moodle platform so that it can accommodate complete learning content. The last factor is speed, this is related to how quickly a message from a media can be revised or corrected. Messages in the form of learning content consisting of material, questions / quizzes, and discussion forums in e-learning can be revised and corrected at any time if there is an error.

By logging in and revising anywhere and anytime, the uploaded content can be quickly updated; this is to increase the credibility of both lecturers and students. This is in line with Adawi's research which states that with the application of distance education based on computers and networks (internet, fax, fax-internet etc.), the dependence on distance and time required for the implementation of education will be overcome, because all that is needed can be provided online so that it can be accessed at any time[14].

Seven factors in determining and choosing learning media at Darussalam Gontor University have been well considered so e-learning was chosen. Initial development was limited to the basic subjects of the Communication Science Study Program at Darussalam Gontor University, namely Introduction to Communication Science, Communication Theory, Communication Psychology, Contextual Communication, and Mass Communication. Five courses developed through e-learning will be evaluated and continued with the development of other courses.

\section{Conclusion}

This research has found a communication strategy in the digital era in providing knowledge in Islamic boarding schools through e-learning. The choice of e-learning in learning is determined based on ACTIONS (Access, Cost, Teaching and Learning, Interactivity, Organizational, Novelty, and Speed) factors. The contribution of this study is in the form of communication strategies in the digital era in providing knowledge at Darussalam Gontor University through e-learning. Research on communication strategies in providing knowledge in the digital era can be done by analyzing communicator selection factors, message packaging, and effects. Research recommendations are also intended for policymakers at UNIDA Gontor to maximize the use of e-learning as one of the efforts to support government policies regarding the adjustment of universities in the revolutionary era 4.0.

\section{Acknowledgment}

Ministry of Research, Technology and Higher Education, Director General of Development and Research Enhancement of the Republic of Indonesia

\section{Referensi}

[1] Moh Nurhakim, “Imam Zarkasyi Dan Pembaharuan Pesantren : Rekonstruksi Aspek Kurikulum, Menejemen 
Dan Etika Pendidikan,” Progresiva, vol. 5, no. 1, pp. 83-96, 2011.

[2] D. D. H. Ahmad Damanhuri, Endin Mujahidin, "Inovasi Pengelolaan Pesantren dalam Menghadapi Persaingan di Era GlobalisasiNo Title," Ta'dibuna, vol. 2, no. 1, pp. 17-38, 2013.

[3] H. Cangara, Edisi Revisi Perencanaan \& Strategi Komunikasi. Jakarta: PT Raja Grafindo Persada, 2015.

[4] W. dan D. A. Wardiani, "Strategi Komunikasi Humas Pemerintah Kota Bandung Dalam Menanggulangi Sampah Styrofoam," Linimasa, vol. 1, no. 1, pp. 45-59, 2018.

[5] N. Mahnun, "Media Pembelajaran (Kajian terhadap Langkah-langkah Pemilihan Media dan Implementasinya dalam Pembelajaran)," J. Pemikir. Islam, vol. 37, no. 1, pp. 27-35, 2012.

[6] Agus Prastya, "Strategi Pemilihan Media Pembelajaran Bagi Seorang Guru. Prosiding Temu Ilmiah Nasional Guru," in Prosiding Universitas Terbuka Convention Center, 2016, pp. 294-302.

[7] Asip Suryadi, "Penerapan Model Bates Dalam Desain Diklat Jarak Jauh Online,” 2013, pp. 1-23.

[8] Kementerian Riset Teknologi dan Pendidikan Tinggi Republik Indonesia, "Kebijakan Pendidikan Tinggi Harus Relevan dengan Revolusi Industri 4.0," 2018.

[9] Muhammad Idrus, Metode Penelitian Sosial. Jakarta: Erlangga, 2009.

[10] Sugiono, "Metode Penelitian Kuantitatif, Kualitatif, dan R\&D,” Bandung: Alfabeta, 2016, pp. $273-274$.

[11] W. Purnomo, "Pembelajaran Berbasis ICT," in Workshop Pembelajaran Berbasis ICT, 2008, pp. 1-8.

[12] M. Agustina, "Pemanfaatan E-Learning sebagai Media Pembelajaran,” Semin. Nas. Apl. Teknol. Inf., 2015.

[13] B. O. Tri Darmayanti, Made Yudhi Setiani, "E-learning Pada Pendidikan Jarak Jauh: Konsep yang Mengubah Metode Pembelajaran di Perguruan Tinggi di Indonesia," J. Pendidik. Terbuka dan Jarak Jauh, vol. 8, no. 2, pp. 99-113, 2007.

[14] R. Adawi, "Pembelajaran berbasis e-learning," BAHAS, vol. 69, pp. 1-12, 2003. 